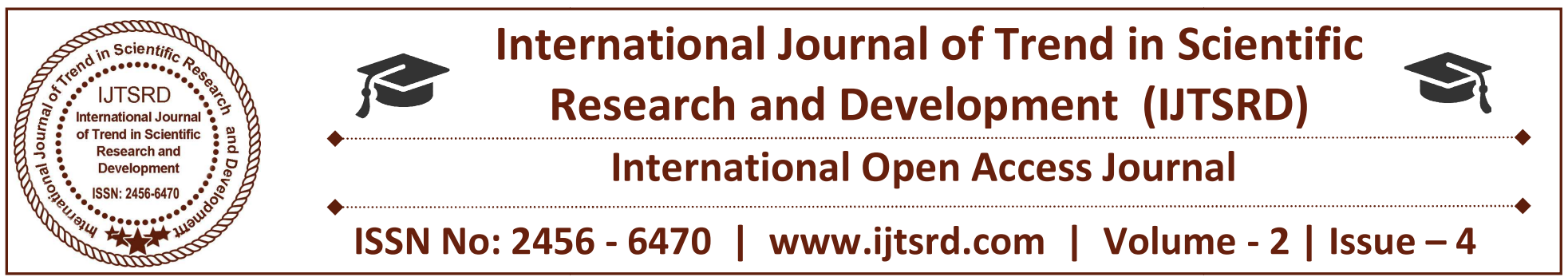

\title{
Study of Role of RTI ACT to prevent Corruption and Capacity building for delivery of government services: Socio-economic impact
}

\author{
Vennapusa Aswartha Reddy
}

Department of Political Science, Osmania University, Hyderabad, Telangana, India

\begin{abstract}
Right to Information Act 2005 - Equated the Common Citizen with the elected Representative of Public with respect to obtaining information, of course, with some exemptions. This act was based on the rights of the common citizens, came into force on October 12th, 2005, empowering the citizens to obtain the information from any public authorities within the prescribed time limit. It enhances the general public to know where the information is available Public authorities and the vital information regarding public authorities are expected to provide suo motu.
\end{abstract}

The information is the ultimate source of power in the common people in the democratic societies. It is access to public records is an essential requirement for a modern government, especially in a democracy. The democracy expects the openness and openness of a free society. The openness is only possible when 'right to know' is exercisable by the people. In a democratic set up the people are sovereign, they have right to know what their representatives are doing. Hence, information is indispensable for the transparency and accountable functioning of a truly democratic government.

\section{The Right to Information Act 2005: An overview}

The Right to Information Act 2005 is indeed acting as a framework for effecting. The right to information has recognized under Article 19 of the Constitution of India. The controversy whether the right to information is included in the fundamental right to freedom of speech contained in Article 19(1). The Constitution of India or not has since been settled and the Supreme Court which finally held that the right to information is as much a fundamental right as the freedom of speech. "This pronouncement has radically changed the very approach of understanding of the right to freedom of information." 10 The proper enjoyment of the right as mentioned under Article 19(1). It is imperative that there must be knowledge and information. The Right to Information Act, 2005 has been enacted by the Parliament, while repealing the 2002 Act, for setting out the practical regime of right to information with a view to creating an environment of transparency and sharing of information and provide every. The Indian citizen the basic constitutional and democratic right has gained access to certain information that may be held by public authorities. It primarily seeks to encourage and enhance transparency and accountability while intending to curb corruption. The act also has overriding provisions over the Official Secrecy Act 1923. Thereby enables the officials to provide information that is otherwise considered by them as an official secret. Further, this act also equated the common citizens to the elected member of the legislation or parliament with respect to obtain information without informing the reasons.

\section{Drawbacks of the Right to Information Act, 2005}

The Right to Information Act is good but it suffers many errors. This law encourages people to gather information. The problem is when $35 \%$ of the population is illiterate. They predicted they would demand information. The government should work hard to improve the literacy level. [14] The RTI Act does not have the necessary teeth for applicants. In cases where the information was rejected without 
sufficient reason. The penalty is not as strict as having a different effect on those who do not like to share information.

\section{NEED FOR THE STUDY}

Public authority did not inform an ordinary citizen until 2005. The process of deciding the citizens to influence or harm people in matters related to legal rights such as food ration cards, basic education, and healthcare. Since it does not have any relevant information, it is not possible for politicians to participate in a meaningful debate on the options available to them to understand economic and financial choices or social-economic aspirations. Constitution of India Section 19 provides freedom of expression and speech to citizens of India. As of 2005, citizens are not aware of public policies and costs. Hence, a citizen will examine and examine public actions to provide a view to rectifying deficiencies in planning and program planning. The whole development process was secretly kept the secret under the Official Secret Act, 1923. Has contributed to massive expenditure for the people and people who have voted for the formation of a democratic government, which have no legal rights to implement policies that are designed to implement them, execution of decision-making processes, and relevant authorities regarding the implementation of the schemes.

\section{The preamble of the RTI Act 2005:}

The law is the heir to the "Freedom of Information Act" and is called "Right to Information Act, 2005". Indicated a definite duration of the law initiated. It definitely comes from running for 120 days. This is a law to establish a practical rule of right to inform citizens to access information in public control. It is in the process of promoting transparency and accountability in the performance of each public 46 authority. Democracy requires transparency of citizenship and information that is important for its performance.

1. This law gives people the opportunity to request information from public authorities.

2. Government officials will become accountable for information on a specific period.

3. There are punitive acts built into law if the public authority does not provide information, delay or false information.
4. The Constitution of an independent Commission ensures that the State and the Center will monitor and monitor law enforcement.

\section{The Salient Features of Right to Information Act, 2005}

This law applies to all public officials, which are of importance:

- Controlled, direct or indirectly financially funded by the government, and includes nongovernmental organizations funded by the government.

- The law of law applies both Houses of Parliament and State Legislatures.

- Subordinate courts, including the Supreme Court, the High Court, their administrative offices, the Election Commission, the Controller and the Auditor General and the Constituent Officers such as the Union Public Service Commission.

- Domestic and foreign private companies operating in the country are excluded from the scope of the Act.

- Any authority or body or organization established or constituted by or through the Constitution; Any law made by the appropriate Government or,

There are a few categories excluded from disclosure under Sections 8 and 9 of the Act. For example, the opportunity to influence the information.

- State security, scientific and financial interests to conduct and investigate the crimes of international organizations in state recognition and investigation.

- All government and its parastatal organizations in central and state governments. Therefore, all state and central government departments such as the Department of Education, Union Health Department, District Panchayat; Offices in the district etc.

- All organizations like cooperative societies, schools, colleges, universities and specific projects.

- It is supported by government funding. Therefore, organizations such as Milk Federation, 
Cooperative Banks, Universities and Public Schools will come under the law.

- State or central government supports Banks and other financial institutions. In fact, there is no confusion whether RTI will apply to banks first.

- After the Reserve Bank has been directed by the Government of India to implement RBI, other banks will be directly operated through this Act.

- All non-governmental organizations receiving grants from a minimum of Rs 50000 per year are required to follow the Right to Information Act and the Cabinet documents.

\section{Role of Central/State Government in RTI Act Implementation}

Central / State Government plays a key role in law enforcement. The Act specifies that the RTI, specifically aimed at developing and developing educational programs for the purpose of promoting awareness for the backward sections of the public, training PIOs and producing relevant training equipment for public utilities. They can make rules regarding fees and expenses for access to information. Government Ministries and departments are responsible for preparing annual reports and maintaining records for such purposes. Hence, the RTI message has been allocated to people of the state/state government in different ways.

\section{Promotion of Citizen-Government Partnership}

The RTI Act provides a plan to promote civicgovernment partnership in taking care of the welfare of the people. The principle of partnership is not only the ultimate beneficiaries of development but also the development agents. Shareholders' participation leads to improved projects and more development that is powerful. Under the RTI Act, encouraging participation of citizens (a) has been encouraged by the introduction of groups/communities affected by the design and implementation of information and projects; And (b) Empowerment of Local Government Institutions at Rural Level, Empowerment, and Cooperation with NGOs / Self Help Groups. The active exposure of the information has enabled the beneficiaries to play a key role in designing and implementing the projects. The ownership of RTI development programs is widely understood. Furthermore, this information is available to people to participate in economic and political processes through dialogue between people, government officials or public campaigns.

\section{Reduction in Corruption}

Transparency and accountability are encouraged by government officials to engage in corrupt practices, leading to less investment from misuse or redress of funds for private purposes. As a result, government social spending is not profitable, for example, teachers do not, doctors and nurses cannot attend health centers, and ration cardholders do not receive subsidized food grains and people who have promised jobs. In this process, it will poverty permanently and harm to the poor. This creates an atmosphere of distrust between people and the government, which will have an impact on development and harm the democratic governance. Under the RTI Act, there is an unprecedented transparency in the work of government departments. As a result, there is more awareness of the decisionmaking process and the high public accountability of the government.

\section{CONCLUSION}

The study began to determine whether the actual decision to collect often from the government. The RTI Act is widely misused by citizenship. This filters a large number of unpleasant, impractical and objectionable applications. It is important that the RTI Act filed by the applicants in the country. Without mentioning the RTI Act, the RTI Act has to be given to the people in many cases without filing an application.

\section{REFERENCE:}

1. Acharya N. K., "Commentary on Right to Information Act, 2005”, 6th ed.

2. Aminuzzaman, M.S., 1991. Introduction to Social Research. Dhaka: Bangladesh Printers.

3. Anderson and Pasker. 1964. Society, New York: Van Nostrand Company

4. Aggarwal Mayank, "Coming soon: RTI's success story on your TV", DNA, New Delhi, October 7, 2011

5. Basu, D.D. Constitutional Law of India, (8th Edn. Vol. 3), at p. 4087. Chandler, J. A., 2001.Local Government Today. Manchester: Manchester University Press. 
6. Gandham, Suresh Kumar, "The Right to Information in India-A study" Supreme Court Journal 2009 (Journal)

7. Kashyap Hemant, "Death row cop files RTI plea", Mumbai Mirror, March 4, 2011.

8. Monga, A. (2008). E-government in India: Opportunities and challenges, JOAAG,

9. P.B.Sawant, "Right to Information" Press Council of India Review 1997 May-July:

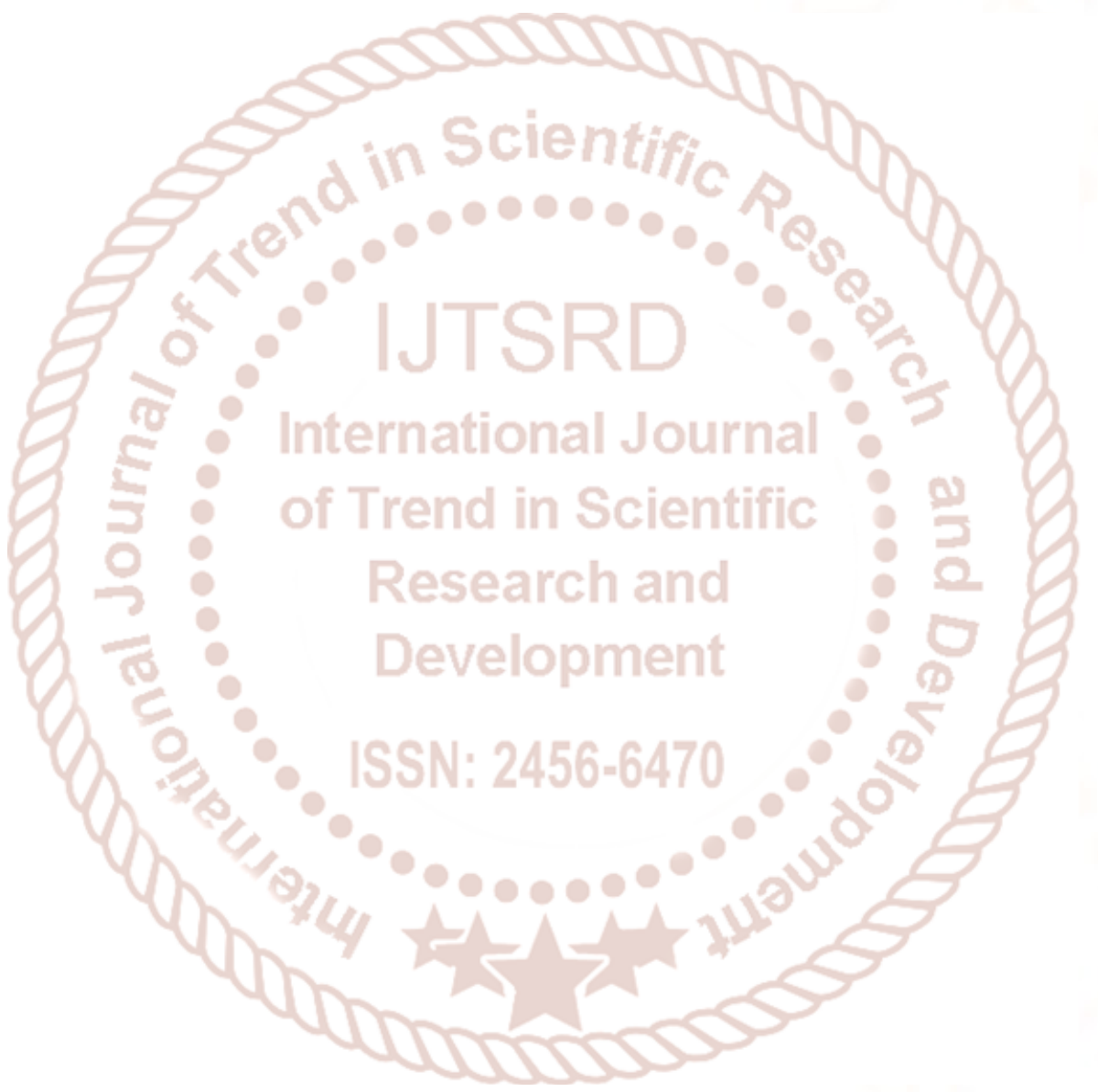

